\author{
Prokopenko, G.I. ${ }^{1}$, Mordyuk, B.N. ${ }^{1}$, \\ Krasovsky, T.A. ${ }^{2}$, Knysh, V.V. ${ }^{3}$, and Solovey, S.0. ${ }^{3}$ \\ ${ }^{1}$ G.V. Kurdyumov Institute for Metal Physics of the NAS of Ukraine, \\ 36, Acad. Vernadski Boulevard, Kyiv, 03142, Ukraine, \\ +380 44424 1005, +380 44424 2561, metall@imp.kiev.ua \\ ${ }^{2}$ Kyiv Academic University of the NAS of Ukraine, \\ 36, Acad. Vernadski Boulevard, Kyiv, 03142, Ukraine, \\ +380 44424 8250, +380 44424 8250, taraskras@gmail.com \\ ${ }^{3}$ Paton Institute of Electric Welding of the NAS of Ukraine, \\ 11, Kazimir Malevich St., Kyiv, 03150, Ukraine, \\ +380 44200 4779, +380 44528 0486, office@paton.kiev.ua

\section{CREATION OF INDUSTRIAL EQUIPMENT FOR HIGH FREQUENCY MECHANICAL IMPACT ON RAILWAY CAR BUILDING PRODUCTS AND METHODS FOR ASSESSING THE QUALITY OF TREATMENT}

Introduction. The technology of high-frequency mechanical impact (HFMI) has proved itself to be a reliable, efficient, and convenient method for increasing the fatigue strength of welded structures, which is one of the most priority tasks of the machine-building industry.

Problem Statement. The experience of operating the HFMI equipment and technology has shown that there are many problems associated with the determination of the process quality and completeness. The creation of ultrasonic equipment for HFMI with electromechanical piezo-ceramic transducers was initiated at the Kurdyumov Institute for Metal Physics of the NAS of Ukraine. Over the years, this equipment has been used both for scholarly research and for processing of various products and structures. However, neither the HFMI equipment nor HFMI technology has been commercialized so far.

Purpose. To create a new ultrasound equipment having a high reliability and a significant operation resource suitable for the use in the operating conditions and to develop tools for evaluating the HFMI process quality regarding welded joints of certain parts and railway-car building products.

Materials and Methods. Low-alloy structural steels St3cp and 09G2S. Hardness/microhardness measurements and optical microscopy.

Results. A mock-up of ultrasonic equipment has been made. It has passed comprehensive industrial tests at Kryukovsky Railway Car Building Works, Public Joint-Stock Company (KRCBW PJSC), Kremenchuk, Ukraine. Some deficiencies of the equipment identified during the tests have been eliminated in a new model of the equipment. A method for determining the HFMI process productivity and the duration of treatment of welded joints has been suggested. It is based on simple microhardness measurements. The quality and completeness of the treatment has been additionally checked by visual inspection of a groove formed by impact elements.

Conclusion. A new ultrasound equipment has been manufactured, and technological recommendations on choosing treatment conditions for railway carriage trolleys and other products of KRCBW PJSC have been proposed.

Keywords: high-frequency mechanical impact, metal fatigue, welded joints, microhardness, ultrasonic equipment, and quality and duration of treatment.

(C) PROKOPENKO, G.I., MORDYUK, B.N., KRASOVSKY, T.A., KNYSH, V.V., and SOLOVEY, S.O., 2019 
Increasing the fatigue strength, reliability, and durability of machine-building components and products, especially, the welded structures operating under cyclic stress, is one of the most urgent problems in the machine-building industry. One of the lines for extending the service life of machine parts and products is the creation of new, highly effective methods for surface modification, including severe plastic deformation, by ultrasonic impact treatment (UIT) that is known in the Ukrainian literature as high-frequency mechanical impact (HFMI). High frequency of impacts and their considerable power make this method the most effective in terms of efficiency factor, surface quality, and record-breaking increase in fatigue strength. Insignificant weight and dimensions of ultrasonic equipment enable to use it in factory shops or in field conditions. A low power consumption puts the HFMI technology on the leading position among conventional methods for strengthening welded joints. Optimizing technology by developing instrumental methods for evaluating the quality parameters of welded joints will raise the efficiency of treatment and improve economic performance by reducing time inputs. Widely introducing the developed ultrasound equipment in various sectors of the national economy will enhance the operational reliability of different structures, which prevents their early mechanical failure, has significant economic and social effects, and corresponds to the innovative approach to the development of Ukrainian industry in terms of resource-saving.

In the early 1970s, the Kurdyumov Institute of Physics of Metals and the Paton Institute of Electric Welding of the NAS of Ukraine have started a joint study of HFMI effect on the level of residual stresses in welded joints [1]. Later, this area of applied scholarly research became the basis for creating a technology for increasing the fatigue strength of critical welded structures using the HFMI method.

The weld strength is known to be insignificant, primarily, because of degrading metal structure, as a result of its melting and hardening, and emer- ging stress concentrators and significant tensile stresses in the weld area. Their superimposition on external cyclic stresses leads to an early fatigue fracture in the weld area, which sometimes leads to catastrophic consequences. The tensile stress can be relieved by heating the parts, but this is impossible in the case of large-sized structures. So, in this case, local methods for welded joint treatment are used. The Paton IEW studies have shown that HFMI gives the best results in terms of increase in fatigue strength of samples and structural elements, as compared with other methods of treatment [2, 3]. This technology assumed its name according to the recommendation of the International Institute of Welding (IIW). It has proved itself as a reliable, efficient, and convenient method for increasing the fatigue strength of welded structures [4].

Welding of sheet structures often leads to a change in their geometry due to high internal stresses. Ultrasonic treatment helps reduce these stresses or redistribute them. This is yet another field for the application of this technology. However, in Ukraine, there have been only prototype ultrasonic devices of this type so far. The frontend works at KRCBW PJSC were carried out using prototype plants that had a short service life.

The purpose of this research and its main task is to create a reliable industrial ultrasound equipment for practical application of HFMI technology. To implement this technology, it is necessary to identify feasible and instrumentally measurable quality criteria.

\section{CREATION OF EQUIPMENT FOR HFMI TREATMENT OF MACHINE-BUILDING PRODUCTS}

Ultrasound impact tool. Over recent years, several methods and devices to optimize machining conditions and to obtain a maximum increase in fatigue strength at a high process efficiency and a reduced power consumption have been created for HFMI welds [5, 6]. The most important factor is high reliability of the equipment as it should work for a long time in severe operating environment and, sometimes, in the open air, while trea- 
ting external welded structures. For designing and implementing any technological processes using a strong ultrasound, one of the most important tasks is to choose a method for obtaining mechanical ultrasonic oscillations of a given frequency, amplitude, and power. The technological efficiency and results of technology implementation depend on how efficient this problem is solved. The typical ultrasound system includes an ultrasonic transducer with a system of acoustic mechanical elements and an electronic generator as power supply source. Ultrasonic transducers are devices that convert electrical energy into mechanical one. The ultrasonic frequency oscillations are generated mainly by magnetostrictive and piezoceramic transducers. The latter is widely used to generate powerful ultrasonic vibrations.

Piezoelectric converter (PEC) generates ultrasonic oscillations using a piezoceramic element, to which external AC voltage is applied. Such structural elements consist of two (front and back) metal bars having a cylindrical shape, with piezoceramic rings with an even number (in this case, 4) of discs fixed in between (Fig. 1, $a$ ). The main resonance frequency of such $6 \mathrm{~mm}$ thick discs is $\sim 100 \mathrm{kHz}$. The metal bars provide a reduction in the operating frequency to a low ultrasonic one that for industrial plants is $\sim 20-30 \mathrm{kHz}$. The PEC geometric sizes are calculated taking into account the speed of ultrasonic wave propagation in the materials of the front and back bars and in the piezoelements, as well as density and mass of the latter [7].

Based on theoretical calculations of the known structures [8], it was necessary to create a universal PEC for an impact tool, which provides a minimum damping of the ultrasonic vibrational system (USVS) under severe shock-vibrating loads at the output end of the concentrator that increases the amplitude of oscillations. The known methods for calculating the USVS give only approximate parameters of individual structural elements. In addition, the empirical formulas with the use of experimental results is a labor-intensive process and requires cumbersome arithmetic.
It should be noted that verification of the calculated values is possible only after the manufacture and assembly of the vibrational system with subsequent measurement of its parameters. Typically, the USVS is designed in several stages:

1) preliminary calculation according to the given parameters (using the known methods);

2) adjustment of the geometric dimensions of the PEC components;

3) manufacture of parts of the designed structure and assembly;

4) separate measurements of the USVS parameters, including those with the use of work tools;

5) final calculation with adjustment of parameters taking into account the results of experimental studies;

6) finalization of the created USVS and work tool for adjusting with main resonance frequency.

The USVS has been developed using AutoCAD automated graphic design system in $3 \mathrm{D}$ format with the subsequent analysis in the ANSYS environment [9]. Based on the proposed method, a PEC operating at a frequency of $\sim 26 \mathrm{kHz}$ (Fig. 1, $a$ ), has been manufactured. It has been completed and aligned with a booster and a step concentrator of ultrasonic oscillations to obtain the required amplitude of oscillations. According to the specification requirements, the converter for HFMI is made in an enclosed casing. If the amplitude of oscillations at the concentrator muzzle end ranges within $20-25 \mu \mathrm{m}$, the temperature of the piezoelectric cells may exceed a maximum permissible temperature of $+80^{\circ} \mathrm{C}$. Since the equipment will be used in ambient conditions at a temperature from $-10^{\circ} \mathrm{C}$ to $+35^{\circ} \mathrm{C}$ and in factory workshops during throughout the operating shift, special attention is paid to compulsory cooling of the device all through the regulated processing time, depending on the amplitude of ultrasonic vibrations and the external temperature.

Due to impact interaction with the core elements that deform the metal surface, the converter receives mechanical loads with a vibration frequency ranging from 40 to $1000 \mathrm{~Hz}$ and an acceleration of $15-300 \mathrm{~m} / \mathrm{s}^{2}$. To reduce vibrations 

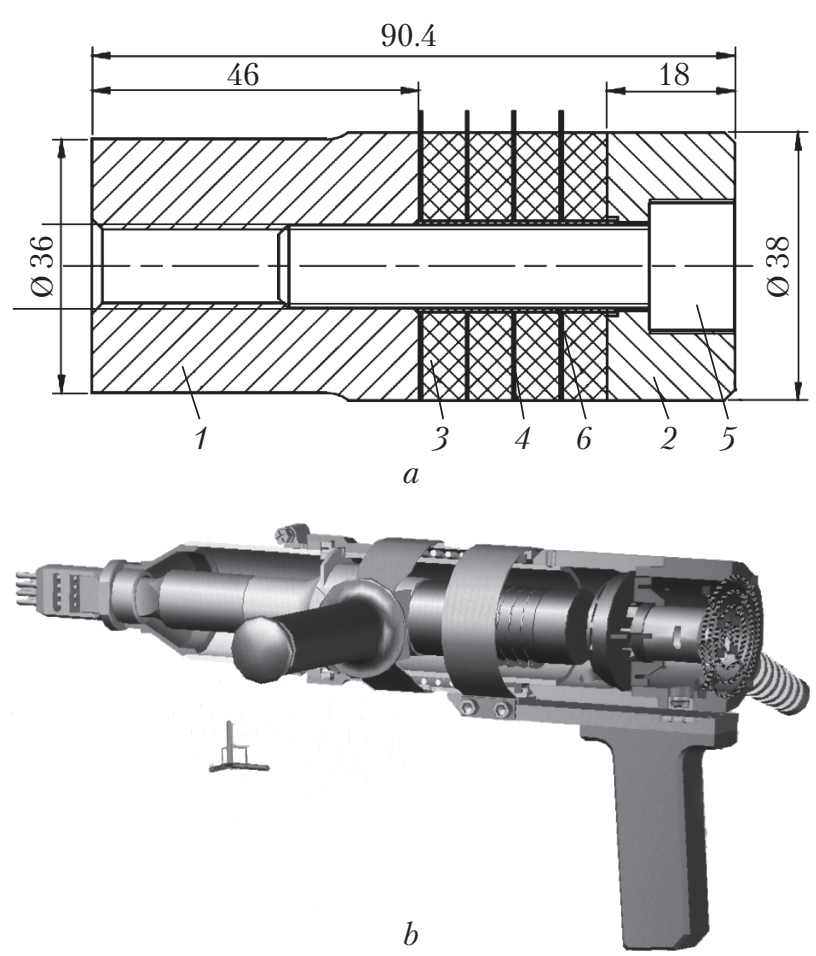

Fig. 1. Drawing of $\sim 26 \mathrm{kHz}$ piezoelectric converter $(a)$ and components of ultrasound impact tool in 3D format $(b)$ : $1-$ front bar Д16Т; 2 - rare bar of 40X13 steel; 3 - piezoceramic element APC841, dimensions $38 \times 16 \times 6 \mathrm{~mm} ; 4$ - copper electrodes ( 4 pieces); 5 - tightening bolt M12×1.5; 6 insulating bushing

of the casing in which the converter is located, shock absorbers and springs with a sufficient pliability and a significant damping are used. Silicone rubber and spring steel are used as elastic elements. This significantly reduces the vibration load on the operator's hands, which does not exceed the permissible values as established in the relevant standards regulating the labor safety when working with the vibration instrument.

The performance and quality of the HFMI process, as well as the temperature conditions of the ultrasonic emitter and the impact load node depend, to a large extent, on the design of both the tool as a whole and its individual components. When designing the tool, the state-of-the-art 3D technology was used. General view of the device designed is shown in Fig. 1, b. The tool is equipped with the main and side handles for ease of operation. In the back of the casing there is mounted a powerful fan for forced air cooling of all parts of the USVS. On the opposite end of the tool, there is a variable shock head with high-strength rod hammers. The number of shock elements in the head and their diameter depend on the type of weld joint or on the geometry of the surface to be treated.

During previous research, we have developed and patented a series of ultrasonic impact tools, including [10]. While implementing an R\&D project of the NAS of Ukraine in 2017, a mockup specimen of ultrasonic equipment was manufactured and tested at KRCBW (Kremenchuk) during 4 months. Based on the test results, there was made a certificate in which the drawbacks of device design and suggestions for its improvement were stated. Subsequently, the ultrasonic generator was improved and a new manual impact tool was made using new technical solutions setting right the mockup specimen drawbacks.

Ultrasound digital generator. The PEC is powered by an ultrasonic electronic generator converting the electric energy of the industrial power grid into the energy of the ultrasonic frequency oscillations. The electronic generator, the PEC, the impact node and the surface of the part (structure) undergoing ultrasonic treatment must be aligned, since they directly affect each other. In this regard, when designing the ultrasonic equipment, it is necessary to ensure optimal adjustment of parameters of the generator and the PEC in the case of any changes in the treatment conditions or external effects.

In view of the drawbacks identified during the operation of mockup specimen at KRCBW, the task was to create an ultrasonic generator (USG) with a new software and a fundamentally new configuration of the casing in which the electrical circuits would be reliably protected from any environmental impact.

During the project implementation, the following works have been done:

1. The scheme of USG with digital phase-automatic frequency setting has been upgraded. The scheme is realized by direct digital synthesis, it has 
an increased range of keeping the resonant conditions under the influence of various destabilizing factors on the piezoceramic emitter, which provides a high level of stability and repeatability of the equipment technical characteristics.

2. A complete set of design documentation, including circuit diagrams, printed circuit boards and drawings of all constituent parts of the USG has been elaborated.

3. A hardware and software complex and a method for adjusting the USG with PEC have been developed and manufactured.

4. A new configuration of the casing for mobile air-cooled USG has been designed. It ensures longstanding operation in the regular conditions, both in the open air and under industrial dust pollution.

Laboratory tests of manufactured ultrasonic equipment have been carried out and shown its compliance with the specifications given in the Terms of Reference. Further tests of advanced equipment for HFMI of some its products have been agreed with the management of KRCBW in order to introduce this innovative technology in the railway car-building industry.

\section{MICROHARDNESS MEASUREMENT-BASED DETERMINATION OF PERFORMANCE OF WELD JOINT TREATMENT BY THE HFMI METHOD}

The greatest progress in the development of HFMI technology is the establishment of the fact that the only way to treat any weld joint is to do this along the line of its fusion with the parent metal, by a single-row multi-hammer tool. This has been confirmed by numerous fatigue tests on specimens treated under different conditions, at the Paton IEW of the NAS of Ukraine [1-3]. At the same time, there is no single methodology that establishes how long it is necessary to treat certain weld sections of different materials. The finishing of the treatment is usually associated with the formation of a lustrous groove having a width that is equal to the hammer diameter $(3-5 \mathrm{~mm})$ and a depth of $0.2-0.6 \mathrm{~mm}$, depending on the strength of the material [4].
Numerous studies of strain concentration during HFMI have shown that structural changes in the surface layer occur over a short period of time, as a result of high frequency of impact. This can be visible on the time dependence of mechanical properties, for example, microhardness. Changing microhardness $H \mu$ over time of HFMI shows that such dependencies are practically the same for most structural materials [6]. In the first seconds of treatment, microhardness rapidly grows to a certain magnitude and then remains almost fixed or even decreases. It should be noted that long treatment of metals by impact methods causes excessive hardness. This, in turn, leads to a noticeable destruction of the surface layer (peeling) and a degradation of mechanical properties. Consequently, there is an optimal time of treatment by the HFMI method per unit of length or surface area $\tau_{\text {опт }}$ for each material, at constant amplitude of oscillation, impact blow frequency, diameter and mass of the hammer. So, measuring the hardness of weld joint before and after HFMI and correlating it with the main parameters the level of residual stresses, the removal of stress concentrators, and the fatigue strength, it is possible to create simple instrumental methods for determining the quality and completeness of treatment, in the production environment.

The studies were made using samples of the parent metal of 09Г2C and Ст3сп sheet steels and their weld joints. The $09 \Gamma 2 \mathrm{C}$ steel sheets was $12 \mathrm{~mm}$ thick, and the $\mathrm{C}_{\mathrm{T}} 3 \mathrm{c} \Pi$ steel sheets had a thickness of $16 \mathrm{~mm}$. Samples with a size of $30 \times 40 \mathrm{~mm}$ were cut from the parent metal. The microhardness of the parent metal and the steel layer that has undergone a plastic strain by HFMI was measured by the PMT-3M device for a load of $50 \mathrm{~g}(0.5 \mathrm{~N})$. Firstly, the microhardness was measured on the lateral surface of original rectangular samples. It is established that it essentially changes with the distance from the surface into the hot rolled coil. Thus, the microhardness of $09 \Gamma 2 \mathrm{C}$ steel surface layer (at a depth up to $0.07 \mathrm{~mm}$ ) is $\mathrm{HV}_{0,5}=460-548 \mathrm{MPa}$, but as the distance from the surface increases $(0.4 \mathrm{~mm}$ and more $)$ it de- 


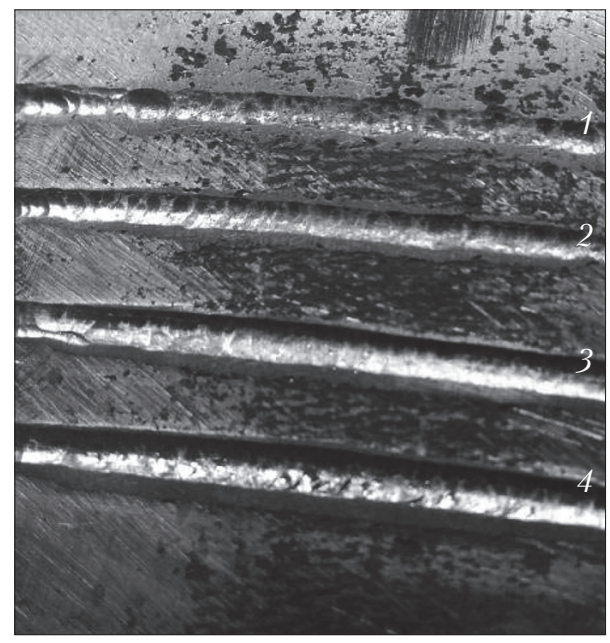

Fig. 2. General view of the hammering area of 09Г2C steel parent metal after HFMI treatment for different duration of treatment: $1-3 \mathrm{~s} ; 2-6 \mathrm{~s} ; 3-12 \mathrm{~s} ; 4-30 \mathrm{~s}$; speed of HFMI treatment $-10.5,2.5$ and $1.0 \mathrm{~mm} / \mathrm{s}$, respectively

creases to $243-278 \mathrm{MPa}$. The same situation is also reported for $\mathrm{C}_{\mathrm{T}} 3 \mathrm{c} n$ steel samples (see Table). Such a wide range of microhardness is explained by a heterogeneous structure of steels.

One can see that the sheet metal has a fairly high surface microhardness that substantially decreases at a depth of more than $0.4 \mathrm{~mm}$ from the surface. This should be taken into account when further treating the sheet metal samples by the HFMI method. Firstly, the conditions and the performance of HFMI treatment of steel samples were determined on the original samples. The HFMI treatment was carried out using a new equipment, with a detachable single-row nozzle having four $3 \mathrm{~mm}$ diameter hammers used as an impact node. The test specimen was treated by the HFMI technology along four $30 \mathrm{~mm}$ long lines (5-7 $\mathrm{mm}$ apart from each other) for 3, 6, 12, and 30 seconds. The HFMI treatment speed was 10, 5, 2.5, and $1.0 \mathrm{~mm} / \mathrm{s}$, respectively (Fig. 2).

It has been established that after the treatment of 09Г2C steel parent metal by the HFMI technology, the microhardness of plastic-strained surface metal layer $\left(\mathrm{HV}_{0,5}\right)$ is $505-674 \mathrm{MPa}$, at a treatment speed of $10 \mathrm{~mm} / \mathrm{s} ; 298-356 \mathrm{MPa}$, at a treatment speed of $5 \mathrm{~mm} / \mathrm{s} ; 332-356 \mathrm{MPa}$, at $2.5 \mathrm{~mm} / \mathrm{s}$; and $674-812 \mathrm{MPa}$, at $1.25 \mathrm{~mm} / \mathrm{s}$. A similar behavior of the microhardness of parent sheet metal has been obtained for Ст3сп steel. The analysis of results shows that, as the speed of treatment slows down, the microhardness firstly decreases and then sharply increases at $1.0 \mathrm{~mm} / \mathrm{s}$. Such a non-monotonic change in microhardness can be explained as follows. Firstly, at a high speed, a shallow groove is formed (Fig. 2, the treatment duration is $3 \mathrm{~s}$ ), with the solid surface of sheet metal practically not destroyed. Then, as the time of treatment increases and the speed of tool movement decreases, a deeper groove is formed, which means the destruction of surface layer to a depth of up to $0.2 \mathrm{~mm}$ (see Table). A significant increase in the microhardness is reported at a speed of HFMI treatment of $1.0 \mathrm{~mm} / \mathrm{s}$, as the surface of steel hardens. This limit speed can be considered the performance of treatment $P(\mathrm{~mm} / \mathrm{s})$ for given parameters of HFMI (amplitude of ultrasonic oscillations, diameter and number of rod hammers, and mechanical properties of the product material). It depends on the duration of treatment $\tau_{\text {оाт }}$ that determines a certain optimal number of strokes per unit of length of the strained material.

The microhardness dependence of metal layer plastically strained by the HFMI method in the impact area has been studied using samples of butt weld joints of 09Г2C and Ст3сп steels. Fig. 3 shows the joints of $09 \Gamma 2 \mathrm{C}$ steel sample in the original state $(a)$ and after the HFMI treatment (b). The butt weld joints of steels have been obtained by double-sided single-arc automatic welding of plates under OP 192 flux (manufactured by Oerlikon, Switzerland), using a $4 \mathrm{~mm}$ diameter

Microhardness of 09Г2C and Ст3сп Sheet Steel at Different Distance from the Surface

\begin{tabular}{|c|c|c|}
\hline \multirow{2}{*}{$\begin{array}{c}\text { Distance from the } \\
\text { surface, } \mathrm{mm}\end{array}$} & \multicolumn{2}{|c|}{ Microhardness $\mathrm{HV}_{0,5}, \mathrm{MPa}$} \\
\cline { 2 - 3 } & 09Г2C steel & Ст3cп steel \\
\hline 0.07 & $460-548$ & $505-585$ \\
0.2 & $405-440$ & $405-423$ \\
0.3 & $278-298$ & $388-401$ \\
Over 0.4 & $243-278$ & $356-405$ \\
\hline
\end{tabular}


Св-08Г1НMA wire. The welding conditions of $12 \mathrm{~mm}$ thick 09 Г2C steel plates are as follows: the first joint: voltage $\mathrm{U}=55 \mathrm{~V}$, current $\mathrm{I}=650$ $700 \mathrm{~A}$, welding rate $\mathrm{V}=26.7 \mathrm{~m} / \mathrm{g}$; the second joint (on the opposite side): $\mathrm{U}=57 \mathrm{~V}, \mathrm{I}=760$ $780 \mathrm{~A}, \mathrm{~V}=26.7 \mathrm{~m} / \mathrm{g}$. The second joint is made, having completed the cooling of the first one. A $30 \times 350 \mathrm{~mm}$ sample of 09 Г $2 \mathrm{C}$ steel joint is cut from a $600 \times 350 \mathrm{~mm}$ welded plate. The sample is hardened using the HFMI technology along four $30 \mathrm{~mm}$ long fusion lines for 3, 6, 12, and $30 \mathrm{~s}$, at a speed of HFMI treatment of $10,5,2.5$ and $1.0 \mathrm{~mm} / \mathrm{s}$, respectively.

The welding conditions of $16 \mathrm{~mm}$ thick Ст3сп steel plates are as follows: the first weld: $\mathrm{U}=55 \mathrm{~V}$, $\mathrm{I}=850-900 \mathrm{~A}, \mathrm{~V}=26.7 \mathrm{~m} / \mathrm{g}$; the second joint (on the opposite side): $\mathrm{U}=56-57 \mathrm{~V}, \mathrm{I}=960-$ $980 \mathrm{~A}, \mathrm{~V}=26.7 \mathrm{~m} / \mathrm{g}$. The second joint is made, having completed the cooling of the first one. A $40 \times 350 \mathrm{~mm}$ sample of steel butt joint is cut from a $600 \times 350 \mathrm{~mm}$ welded plate. The sample is hardened using the HFMI technology along four $40 \mathrm{~mm}$ long fusion lines for $4,8,16$, and $40 \mathrm{~s}$, at a speed of HFMI treatment of 10, 5, 2.5 and $1.0 \mathrm{~mm} / \mathrm{s}$, respectively.

Having treated the joint by the HFMI technology, the weld reinforcement on both sides is mechanically removed and ground to the level of the parent metal. This has made it possible to directly measure the microhardness of metal joint and the layer of the weld metal hammering zone, which has undergone a plastic strain caused by HFMI treatment. The microhardness of the metal joint after the removal of reinforcement in both welded joints is equal to $\mathrm{HV}_{0.5}=228-268 \mathrm{MPa}$. The obtained dependences of microhardness of the metal layer of the hammering zone the butt weld samples for $09 \Gamma 2 \mathrm{C}$ and Ст 3 сп steels on the speed of HFMI treatment are shown in Fig. 4. They practically do not differ from the established dependencies for the parent sheet metals. Therefore, it is advisable to choose the parameters of reinforcement of welded joints by the HFMI technology on the respective samples of parent metals.
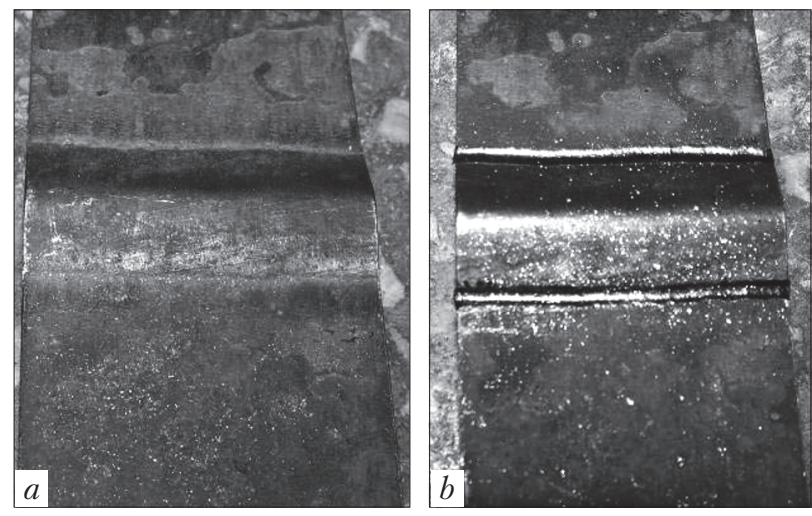

Fig. 3. Butt weld of 09Г2C steel in the original condition after welding $(a)$ and after HFMI treatment $(b)$

The main purpose of preliminary measurements of microhardness is to establish the performance $P(\mathrm{~mm} / \mathrm{s})$ that is measured in treatment speed units. At a HFMI treatment speed of $1.0 \mathrm{~mm} / \mathrm{s}$, the microhardness of the metal layer in the hammering zone is by $50 \%$ higher than that of the original metal layer of $09 \Gamma 2 \mathrm{C}$ rolled steel and by $40 \%$ higher than that of Ст 3 cп sheet steel. The maximum microhardness on the surface in the reinforcement zone correspond to the maximum depth of the layer that has undergone plastic strained as a result of HFMI treatment [2]. Thus, maximum microhardness of metal in the hammering zone can be used as criterion for measuring the performance $P$ that is the limit speed of treatment of welded joints by the HFMI technology. The optimal performance of the treatment of elements of welded structures using the HFMI technology is recommended to be determined based on the criterion for achieving a microhardness of the metal in the hammering zone, which exceeds the respective original microhardness of the surface layer of the metal after rolling. A wide range of compact and mobile micrometers enables measuring the microhardness of a strained metal layer in any spatial position in real welded steel structures.

The optimal performance leads to the formation of a maximally deep strained layer and significant residual compression stresses contributing to the maximum increase in fatigue strength. 


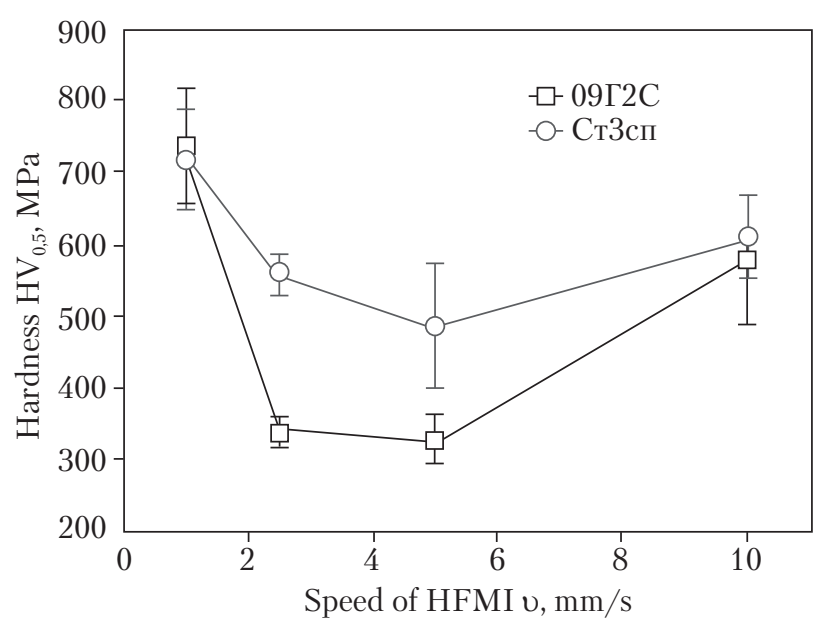

Fig. 4. Change in microhardness of plastic-strained metal layer in the welding area of $09 \Gamma 2 \mathrm{C}$ and Ст 3 сп steel butt weld samples depending on speed of HFMI treatment

It should be emphasized that the performance can be reduced to a certain limit, because it is associated with the duration of treatment, and the optimal duration is determined by the saturation of microhardness or compression stresses. This means that if one continues to reduce productivity, it will result in an excessive increase in the duration of treatment, over-hardened spots, peeling of the surface layer, and a decrease in the fatigue resistance.

The total duration of treatment $T$ of the weld joint having a length $L$ depends on the performance $P$ :

$$
T=L / P .
$$

For example, $100 \mathrm{~mm}$ long 09Г2C steel welds should be treated for $1 \mathrm{~min} 40 \mathrm{~s}$. In manual mode, the operator measures the weld joint length and sets the required duration of treatment on the timer located on the USG front panel. After the completion of treatment, ultrasonic vibrations automatically shut down. However, there is a question "How fast (at which speed $V$ ) should the operator move the tool along the weld joint?" Numerous experimental studies have shown that the speed of treatment $V$ ranges within 10$35 \mathrm{~mm} / \mathrm{s}$ [11]. However, some authors have given much higher values of the speed of treatment, up to $60 \mathrm{~mm} / \mathrm{s}$ [12]. Despite the discrepancy in the values of speed of tool movement while treating welds by the HFMI method given by different researchers, the main parameter is the duration of treatment $T$ during which the impact elements (the hammers) make a given number of strokes per unit of length or surface area of the product. At a frequency of ultrasonic oscillations $\mathrm{F}=18-26 \mathrm{kHz}$, the average frequency of strokes of rod hammers is about $\sim 1.0-3 \mathrm{kHz}$. That is, during the duration of treatment $T$ the total number of strokes is

$$
N_{\text {зад }}=f_{y \partial} T .
$$

In this case, the treatment should be done in a uniform manner and be carried out by reciprocating passes from the beginning to the end of the section to be treated.

Thus, it is necessary to distinguish the performance $P(\mathrm{~mm} / \mathrm{s})$ of the HFMI method from the speed of operator treatment $V(\mathrm{~mm} / \mathrm{s})$ of a certain joint section of length $L(\mathrm{~mm})$. Typically, the treatment is made in several passes along the joint, and the total duration of treatment $T$ (s) is calculated by formula (1). In this case, the operator can make technological pauses stopping countdown on the USG timer and resuming it at the beginning of a new treatment cycle.

\section{DETERMINATION OF QUALITY OF TREATMENT BY THE HFMI METHOD}

Above, there are presented a practical guidance on determining the length and completeness of the HFMI process by instrumental methods. The final stage of this process is assessing the quality of treatment by means of technology, which is realized mainly visually and described in detail in [13]. This work summarizes results obtained by various researchers and published in the IIW documents. The groove quality assessment, as a rule, is done by means of visual inspection after treatment, according to recommendations of the $13^{\text {th }}$ Commission of the International Institute of Welding (IIW). The groove obtained after the HFMI treatment should be smooth along all spe- 
cified weld joints. There should be no visible defects in the groove. To assess the groove quality, it is advisable to use a penetrant or to inspect it with a magnifying glass with an increase from $\times 3$ to $\times 10$. If any defects or flaws in the form of dark stripes or porosity are detected, then to obtain a smooth surface, it is necessary to perform additional passes of the tool in these places. After the HFMI treatment, the groove should be continuous, without any gaps. If the treatment cannot be done without interruptions, for example, in the case of long welds or around the corners, it is recommended to restart it moving back, at least, $10 \mathrm{~mm}$ from the stop position.

The HFMI method in a short time results in a significant local deformation of the material in the area of the weld line. If the rod hammer is directed at a small angle in one particular place, then a sag on the groove side may form as a result of the plastic displacement of metal. Defects of this type should be removed by grinding, and the groove must undergo an additional treatment. Such additional techniques for improving the groove quality enable a significant increase in fatigue strength. Fig. 5 features the results of fatigue tests of flat welds formed as a result of welding of transverse plates. The cyclic loading of the samples at a cycle asymmetry coefficient $\mathrm{R}=0$ was realized on a URS-20 machine, at a frequency of $12 \mathrm{~Hz}$. The Figure shows that the pretreatment of the transition zones of weld joints adjacent to the specimen, for 1 min by a shock head with four $\varnothing 3 \mathrm{~mm}$ hammers leads to an increase in fatigue strength from 110 to $180 \mathrm{MPa}$. After this treatment, individual 1-2 mm long dark stripes were detected on the groove surface. To remove them, the detected defects were additionally treated by a head with a single $\varnothing 4 \mathrm{~mm}$ hammer for $3-5 \mathrm{~s}$. The tests of these samples showed an additional increase in fatigue strength up to $210 \mathrm{MPa}$.

Weld joint preparation. The welded reinforcements and adjacent parent material must be completely cleaned and subjected to minor mechanical machining with metal brushes or grinding to remove all traces of scale, spray and other foreign objects. The HFMI treatment of a convex profile weld or a weld joint at a large angle of weld can lead to a bend in plastic-strained metal over the initial weld and, consequently, to a crack-like defect in the groove. Before treating, the weld profile must meet the limit values for the quality level B according to ISO 5817 [13]. The weld joint defects include undercuts, overfill, overlaps, and the like. If the weld profile does not meet the mentioned quality criteria, a superficial machining before the HFMI treatment may be required. It should be noted that the HFMI procedure is the most effective in the case of treating exclusively the area (line) of the weld between the molten metal and the parent metal. Therefore, grinding operations should be avoided, which complicates the operator's work in terms of determining a precise location of the weld. The decision on the necessity of machining the joints before the HFMI should be made by an experienced operator.

The proper welding profile before the HFMI is necessary because of possible formation of a crack-like defect due to a wrong contact between the hammer and the weld. The visual inspection of such a defect shows a dark line resembling an elongated crack located in the middle of the smooth groove after the treatment. The ultimate fatigue characteristics of the welded joint having such defects may be even lower than that of the weld immediately after the welding. The same defect may be observed in welds with proper profiles, in the case of a wrong diameter of the hammer or too hard treatment, i.e. excessive number of passes in the same area [14]. This confirms the main result of the research, that the duration of treatment $T$ must be determined based on the performance $P$ of a certain material at given parameters of impact load.

Safety requirements. As the experience has shown, noise and vibration in the case of HFMI treatment are much lower than in the case of conventional pneumatic equipment. At the same time, the HFMI treatment, depending on the 


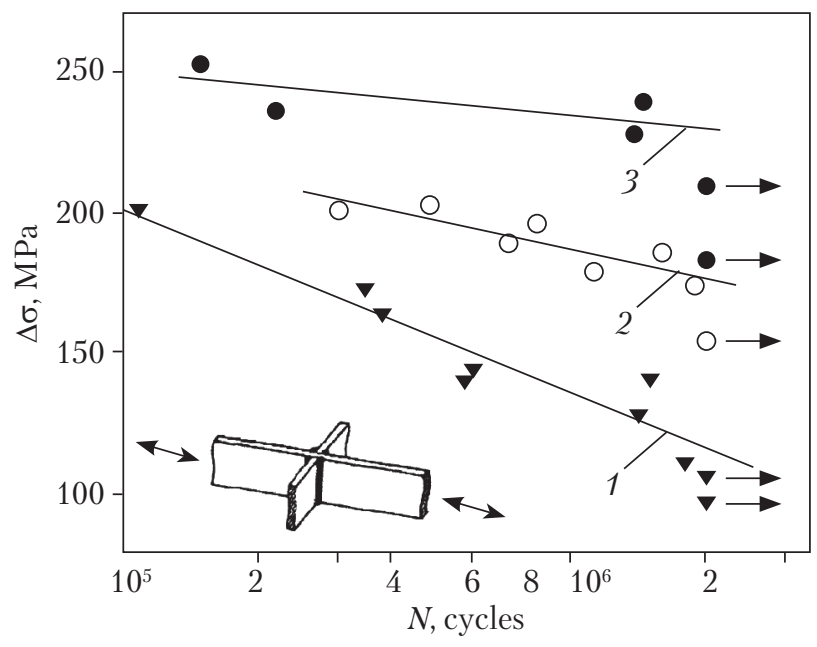

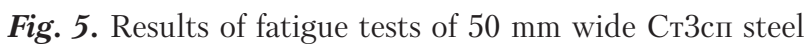
weld samples in the coordinates «maximum strain of variable external load cycle $\Delta \sigma-$ number of cycles before failure $N \gg$ : 1 - after welding; 2 - after treatment of four welds along the welding line, by ultrasound tool (duration of treatment per one weld $-1 \mathrm{~min}$, four $\varnothing 3 \mathrm{~mm}$ hammers, speed of treatment $V \sim 10 \mathrm{~mm} / \mathrm{s}$ ); 3 - additional treatment of groove sections with defects, using one $\varnothing 4 \mathrm{~mm}$ hammer

thickness and dimensions of the structure, can be a rather noisy operation, so it is important that the operator and other people working nearby should use headphones. Protective clothing for work in the shop does not require special conditions, but the operator should have an eye protection. Usually, the vibration transmitted to the operator's hands from the tool during the HFMI treatment is quite low, so the operator should wear light cotton gloves and is allowed to work during a 8-hour shift. If the vibration of a specific tool in the course of the HFMI treatment has not been measured by special tests, working hours may be limited [13].

Quantitative measurements of groove dimensions. The groove depth is an excellent indicator of the degree of treatment by the HFMI method. Depending on the yield strength of steel and the size of indenter, typically, the optimal groove depth after the HFMI treatment is $0.2-0.6 \mathrm{~mm}$ and the optimum width is $3-6 \mathrm{~mm}$. However, it should be noted that no groove size is optimal. In particular, grooves in the high-tensile steel struc- tures, as a rule, are smaller and narrower than those in the low-alloy steels. The groove depth can be checked relatively easily with the use of simple depth sensors. The groove center must correspond to the welding line of weld joint [13].

In the case of HFMI treatment, there is a technological specification that is recommended by the $13^{\text {th }}$ Commission of the International Institute of Welding. Research [15] contains the HFMI-PS specifications to be prepared for each weld of the structure. The HFMI-PS specifications contain information on the treated structure element, parent and welding materials, type of equipment and parameters of power supply, quantity, size, and shape of the used indenter, as well as special technical control requirements and other information. The specifications are developed by respective technological departments of enterprises together with equipment manufacturers for each weld in the structure as a documentary means of guaranteeing the quality of treatment.

The result of this research is the development of a new converter based on piezoceramic rings with a diameter of $38 \mathrm{~mm}$ and a thickness of $6 \mathrm{~mm}$ and a method for calculating its individual components and the ultrasonic oscillation system in general. The harmonization of the acoustic and the electric paths (the converter and the ultrasonic generator) has been improved using recent electronics technologies related to microprocessors and digital control of all ultrasonic frequency oscillation processes.

The main parameter for automatic maintenance of USVS stable operation under various external influences has been established to be the phase determined on the resonant or antiresonance frequency. In order to maintain a given amplitude of USVS mechanical oscillations, the voltage stabilization in parallel resonance mode is used in USG.

The studies of HFMI treatment speed influence on the microhardness of metal in the hammering zone of $09 \Gamma 2 \mathrm{C}$ and Ст $3 \mathrm{c} n$ steels in order to determine the performance of the treatment 
have showed that the performance of weld joint HFMI treatment $P$ can be assessed using the microhardness of metal in the treatment zone, which exceeds the respective microhardness values of the surface metal layer after rolling of sheet semi-finished products.

Practical recommendations on doing the HFMI treatment by manual impact tool have been given and the performance $P$ for the HFMI treatment of $09 \Gamma 2 \mathrm{C}$ and Ст established and is equal to $\sim 1.0 \mathrm{~mm} / \mathrm{s}$. Based on the performance, one can calculate the duration of treatment $T$ of a certain weld joint having a length $L$ to achieve a maximum microhardness of the strained surface. The recommended speed of impact tool movement along the weld is $\sim 10-$
$35 \mathrm{~mm} / \mathrm{s}$. The variation of this value within the established optimal range is explained by the specificity of the "manual" HFMI treatment and does not significantly affect the stability of the hardening parameters and the quality of the surface layer. The weld area (line) between the molten metal and the parent metal of length $L$ should be treated by uniform reciprocating movements within a given time $T$.

The quality of weld joint treatment using the HFMI technology should be assessed by visual and instrumental methods, as recommended by respective documents of the International Institute of Welding. The HFMI-PS specifications that are developed for each weld for various products and structures has been proposed.

\section{REFERENCES}

1. Lobanov, L. M., Kiryan, V. I., Knysh, V. V., Prokopenko, G. I. (2006). Increased fatigue resistance of welded joints of metal structures by high-frequency mechanical forging. Automatic welding, 9, 3-11 [in Russian].

2. Knysh, V. V., Solovey, S. A., Bogaychuk, I. L. (2011). Optimization of the hardening process of 09G2S steel welded joints by high-frequency mechanical forging. Automatic welding, 5, 26-31 [in Russian].

3. Prokopenko, G. I., Knysh, V. V., Solovey, S. O. (2011). Extension of residual resource of the welded joints of St3sp and 09G2S steels by high-frequency mechanical forging. Bulletin of the Ternopil National Technical University. Spec. issue, part 2, 35-41 [in Ukrainian].

4. Lefebvre, F., Peyrac, C., Elbel, G., Revilla-Gomez, C., Verdu, C., Buffiere, J. (2017). HFMI: understanding the mechanisms for fatigue life improvement and repair of welded structures. Welding in the Word, 61(4), 789-799.

5. Prokopenko, G. I., Nedoseka, A. Ya., Gruzd, A. A., Krasovsky, T. A. (1995). Development and optimization of equipment and process of ultrasonic impact treatment of welded joints in order to reduce residual stresses. Technician Diagnostics and Nondestruction Control, 3, 14-22 [in Russian].

6. Patent of Ukraine N 108188. Prokopenko G. I., Mordyuk B. N., Vysokolyan M. V., Volochai V. V., Popova T. V. Method of ultrasonic impact treatment of welded joints of metalic structures [in Ukrainian].

7. Prokiĉ, M. (2004). Piezoelectric Transducers Modeling and Characterization. Switzerland. 266 p.

8. Kiselev, M. G., Savitsky, S. C. (1989). Investigation of operating modes of a technological acoustic system with a movable tool. Priborostroenie, 11, 41-46 [in Russian].

9. Dyakonov, V. P., Penkov, A. A. (1999). Calculation of the control characteristic of transistor voltage transducers with resonant circuit in the MCAD system. Electrical engineering, 4, 54-59 [in Russian].

10. Patent of Ukraine N 94051. Prokopenko G. I., Krasovsky T. A., Cherepin V. T., Mordyuk B. M. Ultrasonic hand tool for deformation strengthening and relaxation treatment of metals [in Ukrainian].

11. Vagapov, I. K., Ganiyev, M. M., Shinkarev, A. S. (2008). Theoretical and experimental research of dynamics of an ultrasonic vibro-impact system with intermediate pin. Proc. of Higher Educational Schools. Mech. Eng., 5, 3-24 [in Russian].

12. Degtyarev, V. A. (2011). Estimation of influence of modes of high-frequency mechanical welding of welded joints on their resistance to fatigue. Strength of Mater., 2, 61-70 [in Russian].

13. Marquis, G., Barsoum, Z. (2013). Fatigue strengthening of steel structures by high-frequency mechanical impact: proposed procedures and quality assurance guidelines. Welding in the World, 57, 803-822.

14. Roy, S., Fisher, J. W. (2005). Enhancing fatigue strength by ultrasonic impact treatment. Int. J. Steel Struct., 5, $241-252$.

15. Lopez Martinez, L., Haagensen, P. J. Life extension of Class F and Class F2 details using ultrasonic peening. IIW Document XIII-2143-06. 


$$
\begin{gathered}
\text { Г.І. Прокопенко }{ }^{1} \text {, Б.М. Мордюк }{ }^{1}, \\
\text { T.А. Красовський }{ }^{2}, \text { В.В. Книш³ }, \text { С.О. Соловей } \\
\end{gathered}
$$

\section{СТВОРЕННЯ ПРОМИСЛОВОГО ОБЛАДНАННЯ ДЛЯ ВИСОКОЧАСТОТНОЇ МЕХАНІЧНОЇ ПРОКОВКИ ВИРОБІВ ВАГОНОБУДУВАННЯ ТА МЕТОДІВ ОЦНКИ ЯКОСТІ ОБРОБКИ}

Вступ. Технологія високочастотної механічної проковки (ВМП) зарекомендувала себе як надійний, ефективний і зручний метод для підвищення втомної міцності зварних конструкцій, що є одним з актуальних завдань машинобудівної галузі.

Проблематика. Досвід експлуатації обладнання та технології ВМП, показав, що існує чимало проблем, пов’язаних із визначенням якості й завершеності процесу обробки. В Інституті металофізики ім. Г.В. Курдюмова НАН України було започатковано роботи зі створення ультразвукового обладнання для ВМП з електромеханічними перетворювачами на п'єзокераміці. Протягом тривалого часу це обладнання застосовувалося як для наукових досліджень, так і для обробки різних виробів і конструкцій. Проте серійного випуску устаткування та широкого впровадження технології ВМП у промисловість не відбулося.

Мета. Розробка нового ультразвукового надійного обладнання зі значним робочим ресурсом, придатного для використання в умовах виробництва, та створення інструментальних методів оцінки якості обробки методом ВМП зварних з'єднань певних деталей та виробів вагонобудівної галузі.

Матеріали й методи. Низьколеговані конструкційні сталі Ст3сп і 09Г2С; методи вимірювання твердості та мікротвердості; оптична мікроскопія.

Результати. Виготовлено макет ультразвукового обладнання, який пройшов різноспрямовані випробування на ПАТ «Крюківський вагонобудівний завод» (Кременчук, Україна). Виявлені в процесі випробувань недоліки було усунуто в новій моделі обладнання. Запропоновано методику визначення продуктивності та тривалості обробки зварних з'єднань методом вимірювання мікротвердості. Якість і завершеність обробки додатково визначається візуальним оглядом канавки, що утворюється під дією ударних елементів.

Висновки. Виготовлено нове ультразвукове обладнання та надано технологічні рекомендації з вибору режимів обробки візків залізничних вагонів та інших виробів ПАТ «Крюківський вагонобудівний завод».

Ключові слова: високочастотна механічна проковка, втома металу, зварне з’єднання, мікротвердість, ультразвукове обладнання, якість і тривалість обробки. 


\author{
Г.И. Прокопенко ${ }^{1}$ Б.Н. Мордюк', \\ Т.А. Красовский ${ }^{2}$ В.В. Кныш ${ }^{3}$, С.А. Соловей ${ }^{3}$ \\ ${ }^{1}$ Институт металлофизики им. Г.В. Курдюмова НАН Украины, \\ ул. акад. Вернадского, 36, Киев, 03142, Украина, \\ +380 44424 1005, +380 44424 2561, metall@imp.kiev.ua \\ ${ }^{2}$ Киевский академический университет НАН и МОН Украины, \\ ул. акад. Вернадского, 36, Киев, 03142, Украина, \\ +380 $444248250,+380444248250$, taraskras@gmail.com \\ ${ }^{3}$ Институт электросварки им. Е.О. Патона НАН Украины, \\ ул. Казимира Малевича, 11, Киев, 03150, Украина, \\ +380 44200 4779, +38044528 0486, office@paton.kiev.ua

\section{СОЗДАНИЕ ПРОМЫШЛЕННОГО ОБОРУДОВАНИЯ ДЛЯ ВЫСОКОЧАСТОТНОЙ МЕХАНИЧЕСКОЙ ПРОКОВКИ ИЗДЕЛИЙ ВАГОНОСТРОЕНИЯ И МЕТОДОВ ОЦЕНКИ КАЧЕСТВА ОБРАБОТКИ}

Введение. Технология высокочастотной механической проковки (ВМП) зарекомендовала себя как надежный, эффективный и удобный метод для повышения усталостной прочности сварных конструкций, что является одной из актуальных задач машиностроительной отрасли.

Проблематика. Опыт эксплуатации оборудования и технологии ВМП, показал, что существует множество проблем, связанных с определением качества и завершенности процесса обработки. В Институте металлофизики им. Г.В. Курдюмова НАН Украины были начаты работы по созданию ультразвукового оборудования для ВМП с электромеханическими преобразователями на пьезокерамике. На протяжении многих лет это оборудование применялось как для научных исследований, так и для обработки различных изделий и конструкций. Однако серийного выпуска оборудования и широкого внедрения технологии ВМП в промышленность не произошло.

Цель. Создание нового ультразвукового надежного оборудования со значительным рабочим ресурсом, пригодного для использования в условиях производства, и разработка инструментальных методов оценки качества обработки методом ВМП сварных соединений определенных деталей и изделий вагоностроительной отрасли.

Материалы и методы. Низколегированные конструкционные стали СтЗсп и 09Г2С; методы измерения твердости и микротвердости; оптическая микроскопия.

Результаты. Изготовлен макет ультразвукового оборудования, который прошел всесторонние испытания на ПАО «Крюковский вагоностроительный завод» (Кременчуг, Украина). Выявленные в процессе испытаний недостатки были устранены в новой модели оборудования. Предложена методика определения производительности и продолжительности обработки сварных соединений методом измерений микротвердости. Качество и завершенность обработки дополнительно определяется визуальным осмотром канавки, которая образуется под действием ударных элементов.

Выводы. Изготовлено новое ультразвуковое оборудование и представлены технологические рекомендации по выбору режимов обработки тележек железнодорожных вагонов и других изделий ПАО «КВСЗ».

Ключевые слова: высокочастотная механическая проковка, усталость металла, сварное соединение, микротвердость, ультразвуковое оборудование, качество и продолжительность обработки. 